\title{
How to Manage Careers in Slovak Small and Medium- sized Wood-processing Enterprises
}

\author{
Miloš Hitka, ${ }^{a}$ Lenka Ližbetinová, ${ }^{\mathrm{b}}$ Jarmila Schmidtová, ${ }^{\mathrm{a}}$ Žaneta Balážová, ${ }^{\mathrm{a}}$ Silvia \\ Lorincová, ${ }^{\mathrm{a}}$ Peter Štarchoň, ${ }^{\mathrm{c}}$ Alžbeta Kucharčíková, ${ }^{\mathrm{d}}$ and Mariana Sedliačiková ${ }^{\mathrm{a}, *}$
}

\begin{abstract}
Current approaches to human resource management are focused on the sustainable development of small and medium-sized enterprises (SMEs). Career strategies of employees are its integral part. The aim of this paper is to determine the changes in professional priorities of employees in small and medium-sized wood-processing enterprises in the area of motivation relating to career aspiration throughout the course of life. The research outcomes show significant correlation between age, gender, and motivation factors relating to career aspiration. Slovak women working in SMEs prefer motivation factors relating to finances, mutual relationships, work, and career aspiration. Motivation factors selected by men are almost the same. In terms of age, motivation factors relating to career aspiration are preferred mainly by women aged 30 to 40 years old. Mentioned factors become less important for respondents of older age groups. Men working in SMEs prefer the motivation factors relating to career aspiration at the age of 30 and subsequently they become less important as well. Following the outcomes of this research, managers of SMEs should motivate careeroriented employees especially according to their needs. In the long-term perspectives, managers can encourage employees to stay focused on their careers.
\end{abstract}

Keywords: Career; Motivation factors; Strategy; Wood-processing; SMEs

Contact information: a: Faculty of Wood Sciences and Technology, Technical University in Zvolen, Masaryka 24, 96053 Zvolen, Slovakia; b: Faculty of Corporate Strategy, Institute of Technology and Business České Budějovice, Okružni 517/10, 37001 České Budějovice, Czech Republic; c: Faculty of Management, Comenius University in Bratislava, Odbojárov 10, P.O.BOX 95, 82005 Bratislava 25, Slovakia; d: Faculty of Management Science and Informatics, University of Žilina, Univerzitná 8215/1, 010 26 Žilina, Slovakia; *Corresponding author: mariana.sedliacikova@tuzvo.sk

\section{INTRODUCTION}

The process of achieving life goals is never simple; it is often about overcoming obstacles and challenges due to the changes of human values over time as they mostly reflect experiences related to age or jobs. Life dynamics, technology development, and environmental changes provide other factors affecting the changes in human nature. Tolbize (2008) presumes that shared events influence and define each generation. While individuals in different generations are diverse, they nevertheless share certain thoughts, values, and behaviors because of the shared events. Furthermore, these values, reactions, and behaviors presumably differ across generations (Zemke et al. 2000). Tolbize (2008) found that as the age increased, reported work ethics decreased, indicating that younger workers reported higher work ethics than older workers did. Younger adults are more motivated to achieve growth and gains (i.e. optimization), and older adults are more motivated to preserve what they have already (Freund 2006). Younger workers, like their older counterparts, want to be respected, although the understanding of respect among 
older and younger workers differs (Deal 2007). Older workers want their opinions to be given more weight because of their experience and they prefer for people to do what they are told, while younger workers want to be listened to and want people to be aware of what they have to say. Furthermore, older people may not appreciate equal respect being shown to all, and may want to be treated with more respect than one would show someone at a lower level in the hierarchy or with less experience. Kanfer and Ackerman (2004) suggest that age-related changes in motivational variables, rather than chronological age or cognitive abilities per se, play a key role in successful work outcomes for middle-aged and older workers. The generations differ in their perceived training needs. Older generations would like skill training in their areas of expertise most, and although younger generations would also like such training, most would prefer training in leadership (Deal 2007; Papp et al. 2017).

The identification of motivation factors relating to career aspiration from a gender and age perspective allows enterprises to differentiate motivation programmes according to the requirements of employees. The research of Byrd et al. (1996), Chenhall and Chapman (2006), Potkány (2008), Arnania-Kepuladze (2010), Kropivšek et al. (2011), Očkajová et al. (2013), Machová (2014), Kampf et al. (2014), Demir et al. (2015), Myšková (2015), Mura and Machová (2015), Fejfarová and Urbancová (2016), Ibidunni et al. (2016), Kmec et al. (2016), Vetráková et al. (2016), Ližbetin and Bartuška (2017), Sardak et al. (2017), and Sánchez-Sellero et al. (2018) indicate that overall performance of small and medium-sized enterprises (SMEs) depends on the employees and their motivation as employees represents one of the strategic factors of company success.

\section{Literature Review}

Outcomes of the research into work activity worldwide shows that young generations especially depend on career to a large extent. Career plays an important role in human life. According to Milkovich and Boudreau (1993) a career is created through a set of rises, stagnations, and falls. Career is a result of purposeful decisions at the level of an individual (Srour et al. 2013). Wilson and Davides (1999) define career in a similar way. According to their opinion, career is a long-term accumulation of education, skills, and experience sold by an individual to an employer in order to provide for appropriate living conditions for him/her and their, respective, family members. Research studies into this field confirm that attitudes toward career are not identical, as it corresponds to the individual's needs (Lord and Farrington 2006; Brown and Lent 2012; Buser et al. 2014). They reflect mainly socio-cultural, age, and gender differences.

Gender stereotypes play a significant role in evaluating gender motivation. Investigations of gender motivation differences are based on the idea of differences between men and women, i.e. on the existence of gender stereotypes which can be traced back to the historical context of male hegemony proceeding from the perception of priority based on sex differences and collaterality of qualitative differences of human beings. Following the theory of gender stereotypes, Arnania-Kepuladze (2010) claims that gender stereotypes as a set of shared beliefs prescribe men and women to behave and be motivated in a different manner. Meece $e t$ al. (2006) found out that gender differences in achievement motivation exist. Reif et al. (1976) examined the significance of particular rewards for men and women and found that gender was the determining factor for the appreciation of the value of reward. Haveman and Beresford (2012) argue that cultural schemas, specifically gender roles and gender norms, explain most individual-level differences between men and 
women and that when cultural factors are ignored, any observed effects of these factors can be dismissed as spurious.

According to Arnania-Kepuladze (2010), today women occupy a significant place in the employment sphere, and their participation in economic life is permanently increasing (Grybaite 2006; Arnania-Kepuladze 2010). Following the finding of Hofstede (2001; 2010), women appreciate friendly atmospheres and usually are concerned about prestige, challenge, task significance, job security, co-operation, and their working conditions. According to Peterson (2004) women prefer to work interactively and seek help from those within their peer group. Inceoglu et al. (2012) say that gender differences can be seen in relation to life changes. For example, women start their family, and their priorities completely change. But findings of Farmer et al. (1998) indicate that women need not feel that they have to give up their social interests to pursue a high prestige science career, since many of these careers combine social interests with investigative and realistic interests. According to Orhan (2000), women are less motivated by wealth creation. The research of Olsen and Walby (2004) shows that gender differences in life-time working patterns account for $36 \%$ of the pay gap. Labour market rigidities, including femaleconcentrated occupations, mean that women are more likely to work in smaller and nonunion firms, which accounts for a further $18 \%$ of the pay gap. Another $38 \%$ is due to direct discrimination and differences in the labour market motivations and the preferences of women as compared to men. The research of Olsen and Walby (2004) further shows that another $8 \%$ is due to lower education completed by women in the past.

Men are highly success oriented and driven. They work hard to achieve high living standards and prefer being able to "show their achievements" (ITIM International 2017). For men, earnings, freedom, advancement, challenge, the possibility to use skills etc. are more significant performance motivators (Bigoness 1988; Arnania-Kepuladze 2010). Long working hours and dedication to work are needed in order to achieve this (ITIM International 2017). Men are independence-oriented, longing for power and authority, selfassertion, popularity, and success (Arnania-Kepuladze 2010; Almobaireek and Manolova 2013). According to Peterson (2004) men prefer to work independently and seek help from those in positions of authority. Men prefer success, autonomy, and achievement (Hofstede 2001; Arnania-Kepuladze 2010; Hofstede 2010).

The investigation of gender motivation peculiarities leads to the finding that motivation relating to finance for men can be characterized as a tendency to make money, autonomy in their work, promotion, recognition, success, and training. On the other hand, the motivation of women tends to be aimed at factors such as cooperation, working conditions, suitable living conditions, and fringe benefits.

The research into the motivation of individual groups is key for understanding the differences in attitudes toward career. Familiarity with the motivation of individual groups of employees in time can help to anticipate motivation development trends in the future. In this research, motivation factors relating to finance, to social needs, to work, to career aspiration, and to mutual relationships were analysed. The motivation factor relating to career aspiration was emphasized. Motivation factors relating to career aspiration can be determined as follows: Opportunity to apply one's own ability is defined as employees are satisfied with working requirements and being engaged, and their job satisfaction is positively affected by self-actualization (Armstrong and Taylor 2015); Career advancement is understood as the climbing of the corporate ladder; Working competences is a set of competences or duties to increase the responsibility associated with the job position; Prestige reflects the social importance of the job position (Farkašová 2015); 
Individual decision-making is the level of independence at work and an increase in job responsibility; Self-actualization is associated with the talent and skill development of an individual employee. Education and personal growth relates to self-actualization and career advancement. Employees improve their skills and abilities and thus improve the business success. Recognition is feedback to an employee relating to work effort.

Employees are one of the sources of the strategic competitive advantage; therefore, the opportunities for their career growth can be beneficial for the staff quality in key positions mainly in SMEs. In the European economy, as well as the Slovak economy, SMEs play an important economic and social role, both through their importance in the economy and in job creation, a role which is greatly appreciated in these times of everincreasing globalization. Small and medium-sized enterprises, especially those operating in the wood-processing industry, represent the crucial source of work opportunities in several regions of the Slovak Republic. The wood-processing industry in the Slovak Republic is not dependent on the import of natural resources; therefore, it is able to show an active balance of foreign trade permanently. In relation to the positive situation related to natural resources, their suitable geographic location, and their acceptable energetic demands for processing wood, the wood-processing industry represents an important field of industry for the Slovak national economy, while thus enabling further development of SMEs (Hajdúchová et al. 2016).

The aim of this paper is to determine to what extent the professional priorities relating to career aspiration in employees working in small and medium-sized woodprocessing enterprises changes throughout the course of their life.

\section{EXPERIMENTAL}

Motivation factors were analysed in Slovak SMEs operating in the woodprocessing industry from 2013 to 2017 . The analysis was conducted as part of an extensive research into the level of motivation after the financial crisis. In terms of financial and economical analysis, the five year long period is considered to be relevant (Kristofik 2002). The selection of respondents was proportionately allocated across Slovakia; therefore, all parts of Slovakia were covered by the research sampling unit. The wood-processing industry in Slovakia was selected, as it still has a relatively small share in the Slovak economy, but based on data of the Slovak Association of Wood Processors, there are more than 7,000 wood-processing companies, with revenues of about 700,000,000 EUR (Hitka et al. 2017).

\section{Data Collection}

A questionnaire was used to determine the level of motivation and to analyse motivational factors. The questionnaires were submitted to randomly selected employees of SMEs operating in the wood-processing industry (primary wood processing, secondary wood processing, furniture manufacturing, paper and paperboard manufacturing) in Slovakia in order to ensure variability and randomness of respondent selection necessary for relevant data acquisition. The method of simple random sampling was used to cover a variety of entrepreneurial entities specialised in the wood-processing industry. Uniform distribution of data within the sampling unit in terms of gender, age, and education of the employees (blue collar workers, white collar workers) was ensured. Over the years 2013 and 2017 the questionnaire was sent via e-mail to 1,300 randomly selected SMEs operating 
in the wood-processing industry. The research data were collected from 1,086 SMEs operating in the wood-processing industry in Slovakia. The sample size was determined using the following equation (Scheer 2007):

$$
n=\frac{z_{\alpha / 2}^{2} \cdot p(1-p)}{\Delta_{p}^{2}}
$$

where $n$ is the size of the dataset, $z_{\alpha / 2}^{2}$ are the values of the standard normal random variable (reliability specified at the $95 \%$ level, i.e. $\alpha=0.05$ corresponds to $\mathrm{z}=1.96$ ), $\Delta p$ is the required exactness (standard error determined at 5.65\%), and $p$ is the ratio (relative frequency) quality sign in the basic set (determined at 50\%). In total, 1,086 completed questionnaires were returned; this corresponds to a questionnaire response rate of $83.5 \%$.

\section{Sample Size}

Socio-demographic and qualification characteristics of employees were studied in the first part of the questionnaire. Basic data collected about respondents included age, gender, seniority, education completed, and job position. A total of 30,823 respondents participated in the research (14,871 women and 15,952 men). A description of the research sampling unit is presented in Table 1.

Table 1. Description of Sampling Unit

\begin{tabular}{|c|c|c|c|c|c|}
\hline Indicator / Year & 2013 & 2014 & 2015 & 2016 & 2017 \\
\hline Number of Enterprises & 212 & 216 & 215 & 218 & 225 \\
\hline Number of Employees & 6,059 & 6,161 & 5,814 & 6,456 & 6,333 \\
\hline Number of Women & 2,952 & 2,908 & 2,805 & 3,186 & 3,020 \\
\hline Number of Men & 3,107 & 3,253 & 3,009 & 3,270 & 3,313 \\
\hline
\end{tabular}

\section{Methods of the Research Evaluation}

The second part of the questionnaire consisted of individual motivation factors. Motivation factors relating to finance (basic salary, fringe benefits, and fair appraisal system), to social needs (social benefits, mission of the company, name of the company, region's development, relation to the environment, and free time), to work (physical effort at work, occupational safety, job security, workload and type of work, information about performance results, working hours, work environment, job performance, and mental effort), to career aspiration (opportunity to apply one's own ability, career advancement, working competences, prestige, individual decision-making, self-actualization, personal growth, and recognition) and to mutual relationships (atmosphere in the workplace, good team-work, communication in the workplace, and the supervisor's approach) were analysed (Hitka 2009; Hitka and Balážová 2015). Motivational factors were in alphabetical order so as not to affect the respondents' decision.

Respondents evaluated individual motivational factors by one of the five levels of importance according to the Likert scale ( 5 - the most important and 1 - unimportant). Statistics 12.0 software (Dell, Oklahoma City, United States) was used to evaluate the results of the research. At the beginning of data processing, the sample dataset, by means of descriptive statistics, was defined (Mason and Lind 1990; Podsakoff et al. 2003; Asparouhov and Muthén 2009). At first, the mean importance values were computed (due to the ordinal character of evaluating score) for five groups of motivation factors. The 
position of the motivation factors relating to career aspiration among other groups of motivation factors, relating to finances, mutual relationship, work, and career aspiration, was displayed.

Because of the nominal level of the collected data, frequency counts were used. The following step was to set up the contingency table. The contingency table classifies data according to two categories associated with each of the two qualitative variables that may or may not depend on each other. Such a table shows observed (or expected) frequencies of all possible combinations of the two categorical variables under consideration.

Within the scope of inferential statistics, dependence between the simple motivation factors relating to career aspiration and the age of employees was investigated. In other words, the question, whether the evaluation of the importance of motivation factors is affected by the age and gender of employees should be answered. The following hypotheses were tested:

WH1: It is assumed that there are significant differences in the motivation factors relating to career aspiration between men and women working in Slovak small and medium-sized wood-processing enterprises.

WH2: It is assumed that there are significant differences in the motivation factors relating to career aspiration among workers at various ages working in Slovak small and medium-sized wood-processing enterprises in terms of gender.

Pearson's chi-square statistics was calculated to test the issue of independence. The most commonly used significance level of $\alpha=5 \%$ was set in all our tests. Following the residual contingency tables, results associated with preferential score values of importance for individual motivation factors relating to career aspiration in terms of an employee age were deduced.

\section{RESULTS AND DISCUSSION} women.

Descriptive characteristics are presented in Table 2 based on responses provided by

Table 2. Descriptive Statistics and 95\% Confidence Intervals for Mean Values of the Importance of Individual Groups of Motivation Factors (Women)

\begin{tabular}{c|c|c|c|c|c|c|}
\hline \multirow{2}{*}{$\begin{array}{c}\text { Motivation } \\
\text { Factors Relating }\end{array}$} & \multicolumn{3}{c}{ Sample } & \multicolumn{2}{c}{ Descriptive Statistics } & \multicolumn{2}{c|}{$\begin{array}{c}\text { 95\% Confidence } \\
\text { Interval }\end{array}$} \\
\cline { 3 - 7 } To & Size & $\begin{array}{c}\text { Number of } \\
\text { Motivation Factors }\end{array}$ & Mean & $\begin{array}{c}\text { St. } \\
\text { Deviation }\end{array}$ & $\begin{array}{c}\text { Lower } \\
\text { Limit }\end{array}$ & Upper Limit \\
\hline Finances & 14,871 & 3 & 4.43 & 0.81 & 4.426 & 4.441 \\
\hline $\begin{array}{c}\text { Mutual } \\
\text { Relationship }\end{array}$ & 14,871 & 4 & 4.41 & 0.78 & 4.404 & 4.417 \\
\hline Work & 14,871 & 9 & 4.13 & 0.88 & 4.122 & 4.132 \\
\hline $\begin{array}{c}\text { Career } \\
\text { Aspiration }\end{array}$ & 14,871 & 8 & 3.99 & 0.91 & 3.984 & 3.995 \\
\hline Social Needs & 14,871 & 6 & 3.94 & 0.99 & 3.935 & 3.948 \\
\hline
\end{tabular}

The mean importance value for the motivational factors relating to career aspiration of women is the second lowest one (3.99) among all analyzed motivational factors. Factors 
relating to finances, mutual relationships, and work are considered by Slovak women to be more important in employee motivation than factors relating to career aspiration and social needs (Table 2). Despite this fact, they are important elements of motivating especially career-oriented employees. At the same time, they are strong predictors affecting employee engagement as well as job satisfaction. Therefore, they must be taken into consideration by employers.

The same situation (Table 3) can be seen also when the importance of motivation factors for men is evaluated (3.94 for men). Factors relating to finances, mutual relationships, and work are considered by Slovak employees to be more important in employee motivation than factors relating to social needs, what is given by the means.

Table 3. Descriptive Statistics and 95\% Confidence Intervals for Mean Values of the Importance of Individual Groups of Motivational Factors (Men)

\begin{tabular}{ccc|c|c|c|c|}
\hline \multirow{2}{*}{$\begin{array}{c}\text { Motivational } \\
\text { Factors Relating }\end{array}$} & \multicolumn{2}{c}{ Sample } & \multicolumn{2}{c}{ Descriptive Statistics } & \multicolumn{3}{c}{$\begin{array}{c}\text { 95\% Confidence } \\
\text { Interval }\end{array}$} \\
\cline { 3 - 7 } To & Size & $\begin{array}{c}\text { Number of } \\
\text { Motivational Factors }\end{array}$ & Mean & $\begin{array}{c}\text { St. } \\
\text { Deviation }\end{array}$ & $\begin{array}{c}\text { Lower } \\
\text { Limit }\end{array}$ & $\begin{array}{c}\text { Upper } \\
\text { Limit }\end{array}$ \\
\hline Finances & 15,952 & 3 & 4.38 & 0.83 & 4.376 & 4.391 \\
\hline $\begin{array}{c}\text { Mutual } \\
\text { Relationship }\end{array}$ & 15,952 & 4 & 4.29 & 0.84 & 4.288 & 4.301 \\
\hline Work & 15,952 & 9 & 4.05 & 0.91 & 0.906 & 0.913 \\
\hline $\begin{array}{c}\text { Career } \\
\text { Aspiration }\end{array}$ & 15,952 & 8 & 3.94 & 0.94 & 3.933 & 3.944 \\
\hline Social Needs & 15,952 & 6 & 3.92 & 1.01 & 3.918 & 3.930 \\
\hline
\end{tabular}

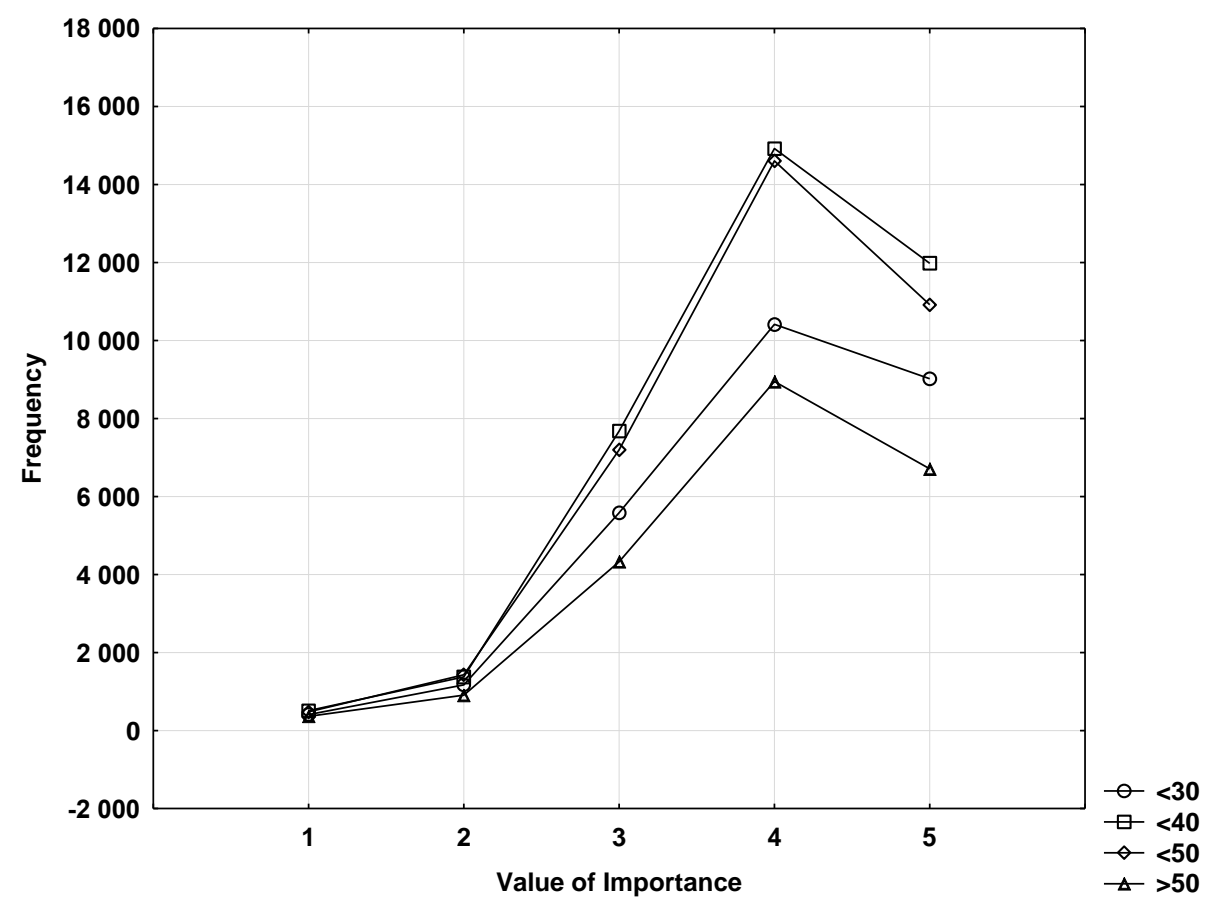

Fig. 1. Absolute frequencies of individual values of importance of motivational factors relating to career aspiration for women depending on age 
Figure 1 shows an assessment of motivational factors relating to career aspiration as a whole in terms of the ages of women surveyed. It was observed that the trend of the response rate was the same across all age groups.

Assessment of motivational factors relating to career aspiration as a whole in terms of the ages of men is illustrated in Fig. 2. The trend of response rate is the same for men in all age groups as well.

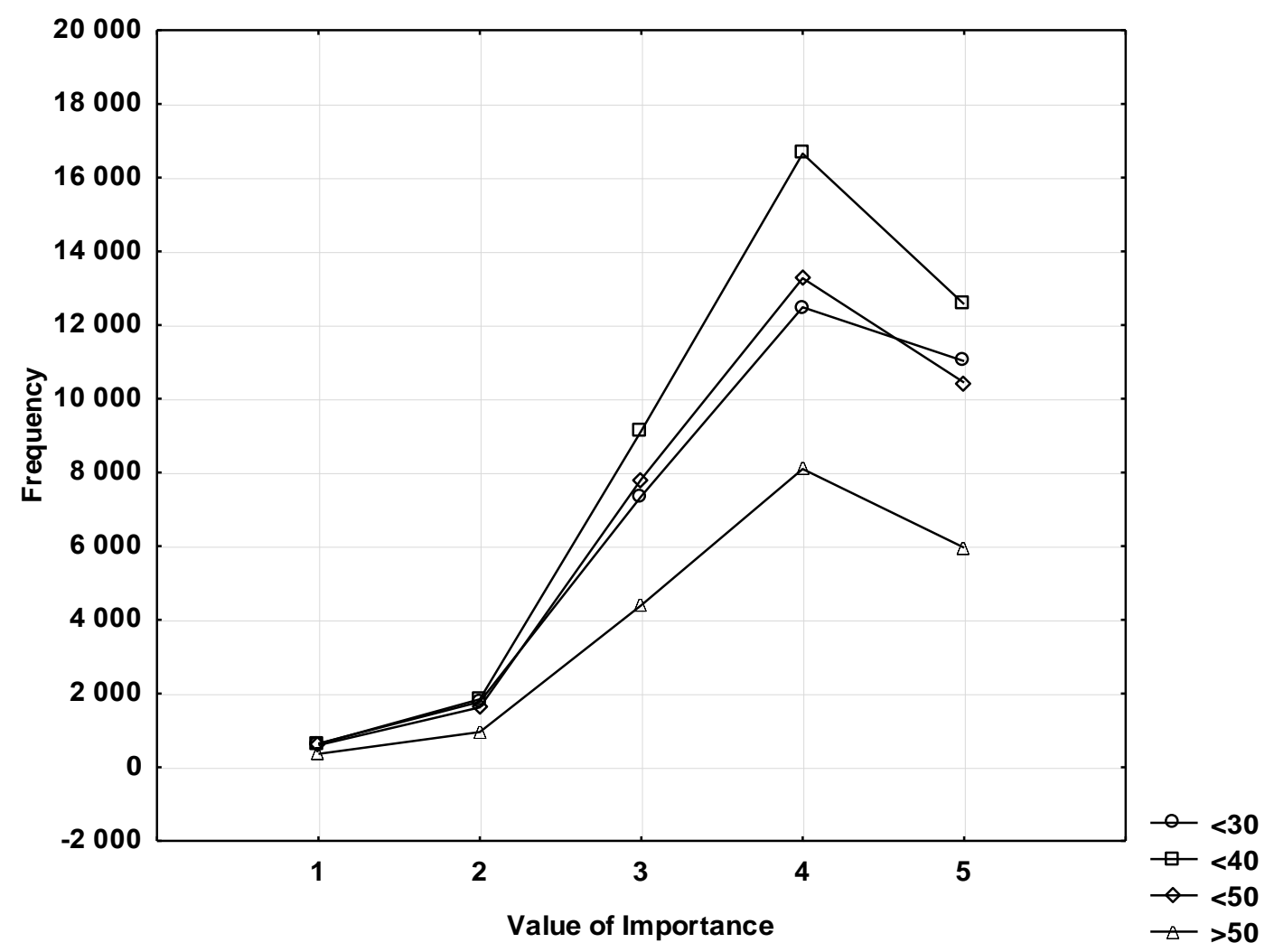

Fig. 2. Absolute frequencies of individual values of importance of motivation factors relating to career aspiration for men depending on age

Table 4 shows the list of eight analyzed motivational factors relating to career aspiration and, subsequently, the review of importance values according to the opinion of respondents, both the women and the men. Relative response frequencies expressed in percentages are mentioned as well. In general, motivational factors relating to career aspiration are considered medium important or important by the dataset consisting of women. The value 4 (important) was the response with the highest frequency in almost all motivational factors relating to career aspiration. However, the most frequent response associated with the motivational factor Recognition was at the level 5 (very important). It is worth mentioning that the motivational factor Prestige was considered unimportant by almost $3 \%$ of women.

Detailed review of motivational factors relating to mutual relationships is shown in Table 5 in order to compare response frequencies. They are mainly rated 5 on the scale (very important). It shows the evidence that Slovak women appreciate positive work relationships. 
Table 4. The Population Proportion of Single Score Values of Motivational Factors Relating to Career Aspiration for Both Women (W) and Men (M)

\begin{tabular}{|c|c|c|c|c|c|c|c|c|c|c|}
\hline \multirow{3}{*}{$\begin{array}{l}\text { Motivational Factors } \\
\text { Relating to Career } \\
\text { Aspiration }\end{array}$} & \multicolumn{2}{|c|}{1} & \multicolumn{2}{|c|}{2} & \multicolumn{2}{|c|}{3} & \multicolumn{2}{|c|}{4} & \multicolumn{2}{|c|}{5} \\
\hline & \multicolumn{2}{|c|}{ 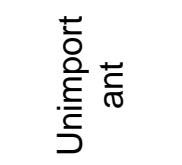 } & \multicolumn{2}{|c|}{ 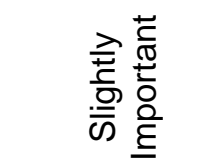 } & \multicolumn{2}{|c|}{ 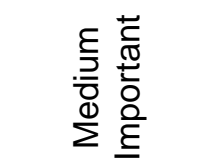 } & \multicolumn{2}{|c|}{ 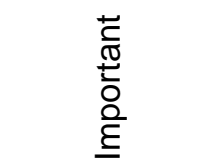 } & \multicolumn{2}{|c|}{ 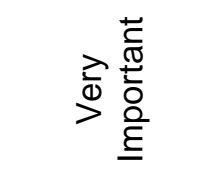 } \\
\hline & W & $M$ & $W$ & $M$ & $W$ & $M$ & $W$ & $M$ & $W$ & $M$ \\
\hline $\begin{array}{l}\text { Opportunity to Apply } \\
\text { One's Own Ability } \\
(\%)\end{array}$ & 1.08 & 1.39 & 3.53 & 4.22 & 17.30 & 18.99 & 44.01 & 43.20 & 34.08 & 32.20 \\
\hline $\begin{array}{c}\text { Career } \\
\text { Advancement (\%) }\end{array}$ & 1.12 & 1.20 & 4.03 & 4.01 & 19.36 & 21.58 & 42.09 & 41.15 & 33.39 & 32.05 \\
\hline $\begin{array}{c}\text { Working } \\
\text { Competences (\%) }\end{array}$ & 1.83 & 2.14 & 4.33 & 5.55 & 26.07 & 25.87 & 39.90 & 38.20 & 27.87 & 28.25 \\
\hline Prestige & 2.61 & 3.13 & 6.83 & & 31.49 & 30.45 & 34.65 & 33.86 & 24.42 & 24.82 \\
\hline $\begin{array}{c}\text { Individual Decision } \\
\text { Making (\%) }\end{array}$ & 1.08 & 1.77 & 4.03 & 4.38 & 19.60 & 21.66 & 45.24 & 41.42 & 30.05 & 30.76 \\
\hline $\begin{array}{c}\text { Self-actualization } \\
(\%)\end{array}$ & 1.32 & 1.45 & 3.71 & 4.51 & 19.81 & 23.03 & 43.14 & 40.57 & 32.02 & 30.43 \\
\hline $\begin{array}{l}\text { Education and } \\
\text { Personal Growth } \\
(\%)\end{array}$ & 1.58 & 1.69 & 3.47 & 4.77 & 17.87 & 19.91 & 40.31 & 39.33 & 36.77 & 34.30 \\
\hline Recognition (\%) & 1.26 & 1.26 & 2.92 & 3.69 & 15.20 & 18.37 & 39.44 & 38.86 & 41.19 & 37.82 \\
\hline
\end{tabular}

Table 5. The Population Proportion of Single Score Values of Motivational Factors Relating to Mutual Relationship for Women

\begin{tabular}{|c|c|c|c|c|c|}
\hline $\begin{array}{c}\text { Motivational Factors } \\
\text { Relating to Career } \\
\text { Aspiration }\end{array}$ & 1 & 2 & 3 & 4 & 5 \\
\cline { 2 - 6 } & Unimportant & $\begin{array}{c}\text { Slightly } \\
\text { Important }\end{array}$ & $\begin{array}{c}\text { Medium } \\
\text { Important }\end{array}$ & Important & $\begin{array}{c}\text { Very } \\
\text { Important }\end{array}$ \\
\hline $\begin{array}{c}\text { Atmosphere in the } \\
\text { Workplace (\%) }\end{array}$ & 0.69 & 1.41 & 7.97 & 32.27 & $\mathbf{5 7 . 6 6}$ \\
\hline Good Work Team & 0.40 & 1.61 & 7.16 & 33.49 & $\mathbf{5 7 . 3 3}$ \\
\hline $\begin{array}{c}\text { Communication in the } \\
\text { Workplace (\%) }\end{array}$ & 0.79 & 2.26 & 10.77 & 36.87 & $\mathbf{4 9 . 3 1}$ \\
\hline Supervisor's Approach (\%) & 0.79 & 2.31 & 8.35 & 31.12 & $\mathbf{5 7 . 4 4}$ \\
\hline
\end{tabular}

Further research into motivational factors relating to career aspiration (Table 6) was focused on the analysis of the most frequent responses from Table 4 (in bold). In terms of the ages of respondents (women and men), the response rating 4 (important) on the scale of selected motivation factors (opportunity to apply one's own ability, career advancement, working competences, prestige, individual decision making, self-actualization, and education and personal growth), and the response rating 5 (very important) of the motivation factor recognition were analyzed. Analyzed motivational factors are considered important especially by women aged 30 to 50 years old. Younger women (up to 30) do not consider the mentioned factors important. It can be supposed that they are more concerned with starting a family. As well as women aged 50+, their career ambitions erode over time.

The most frequent response ranked 4 (important) on the scale from Table 4 (highlighted in bold), in terms of the ages of the respondents for both women and men, was 
analyzed in the research into motivational factors relating to career aspiration (Table 6). Men aged up to 30 years old start to consider the mentioned motivational factors important due to their career progression. The importance of motivational factors relating to career aspiration is growing especially among men aged 30 to 50 years old. At this age, men move up the corporate ladder. Men 50+ do not consider the factors important (their career has been already built up or it is no longer an important issue for them).

Table 6. The Age Category Proportion of Score Value "4" - Importance of Motivational Factors Relating to Career Aspiration for Both Women (W) and Men (M)

\begin{tabular}{|c|c|c|c|c|c|c|c|c|}
\hline \multirow{2}{*}{$\begin{array}{c}\text { Motivational Factors } \\
\text { Relating to Career } \\
\text { Aspiration }\end{array}$} & \multicolumn{9}{|c|}{ Up to 30} & \multicolumn{2}{|c|}{ Up to 40} & \multicolumn{2}{c|}{ Up to 50 } & \multicolumn{2}{c|}{ Over 50} \\
\cline { 2 - 9 } & $\mathrm{W}$ & $\mathrm{M}$ & $\mathrm{W}$ & $\mathrm{M}$ & $\mathrm{W}$ & $\mathrm{M}$ & $\mathrm{W}$ & $\mathrm{M}$ \\
\hline $\begin{array}{c}\text { Opportunity to Apply } \\
\text { One's Own Ability (\%) }\end{array}$ & 20.64 & $23.99 \%$ & 30.46 & 32.52 & $30.23 \%$ & 26.77 & 18.67 & 16.72 \\
\hline $\begin{array}{c}\text { Career Advancement } \\
\text { (\%) }\end{array}$ & 21.15 & $24.19 \%$ & 30.95 & 33.26 & $29.06 \%$ & 26.37 & 18.84 & 16.18 \\
\hline $\begin{array}{c}\text { Working } \\
\text { Competences (\%) }\end{array}$ & 21.87 & $24.85 \%$ & 30.08 & 33.66 & $30.62 \%$ & 26.52 & 17.43 & 14.9 \\
\hline Prestige & 21.19 & $24.09 \%$ & 29.92 & 33.98 & $31.13 \%$ & 26.50 & 17.76 & 15.44 \\
\hline $\begin{array}{c}\text { Individual Decision } \\
\text { Making (\%) }\end{array}$ & 21.40 & $24.34 \%$ & 30.47 & 33.78 & $29.52 \%$ & 25.64 & 18.61 & 16.24 \\
\hline Self-actualization (\%) & 21.70 & $25.53 \%$ & 30.84 & 31.81 & $29.07 \%$ & 26.08 & 17.20 & 16.58 \\
\hline $\begin{array}{c}\text { Education and } \\
\text { Personal Growth (\%) }\end{array}$ & 20.80 & $25.74 \%$ & 30.60 & 32.15 & $29.80 \%$ & 25.50 & 18.80 & 16.61 \\
\hline Recognition (\%) & 21.67 & $25.02 \%$ & 30.74 & 32.83 & $29.82 \%$ & 26.91 & 17.77 & 15.24 \\
\hline
\end{tabular}

Table 7. The Population Proportion of Single Score Values of Motivational Factors Relating to Career Aspiration for Men

\begin{tabular}{|c|c|c|c|c|c|}
\hline $\begin{array}{c}\text { Motivation Factors Relating to } \\
\text { Career Aspiration }\end{array}$ & 1 & 2 & 3 & 4 & 5 \\
\cline { 2 - 6 } & $\begin{array}{c}\text { Unimpor- } \\
\text { tant }\end{array}$ & $\begin{array}{c}\text { Slightly } \\
\text { Important }\end{array}$ & $\begin{array}{c}\text { Medium } \\
\text { Important }\end{array}$ & Important & $\begin{array}{c}\text { Very } \\
\text { Important }\end{array}$ \\
\hline $\begin{array}{c}\text { Opportunity to Apply One's } \\
\text { Own Ability (\%) }\end{array}$ & 1.39 & 4.22 & 18.99 & $\mathbf{4 3 . 2 0}$ & 32.20 \\
\hline Career Advancement (\%) & 1.20 & 4.01 & 21.58 & $\mathbf{4 1 . 1 5}$ & 32.05 \\
\hline Working Competences (\%) & 2.14 & 5.55 & 25.87 & $\mathbf{3 8 . 2 0}$ & 28.25 \\
\hline Prestige (\%) & 3.13 & 7.74 & 30.45 & $\mathbf{3 3 . 8 6}$ & 24.82 \\
\hline Individual Decision Making (\%) & 1.77 & 4.38 & 21.66 & $\mathbf{4 1 . 4 2}$ & 30.76 \\
\hline Self-actualization (\%) & 1.45 & 4.51 & 23.03 & $\mathbf{4 0 . 5 7}$ & 30.43 \\
\hline $\begin{array}{c}\text { Education and Personal } \\
\text { Growth (\%) }\end{array}$ & 1.69 & $4.77 \%$ & 19.91 & $\mathbf{3 9 . 3 3}$ & 34.30 \\
\hline Recognition (\%) & 1.26 & $3.69 \%$ & 18.37 & $\mathbf{3 8 . 8 6}$ & 37.82 \\
\hline
\end{tabular}

Table 7 shows a list of eight analyzed motivational factors relating to career aspiration for men and, subsequently, the review of importance values according to the opinions of the male respondents. Relative response frequencies expressed in percentages are mentioned as well. In general, it can be stated that motivational factors relating to career 
aspiration are considered medium important or important by the dataset consisting of men. The value 4 (important) was the response with the highest frequency in all motivational factors relating to career aspiration.

The dependence between the age and specific motivational factor (Table 8) was verified using inductive statistics as well as Pearson's chi-square test. Following the outcomes of this research, five motivational factors $(\mathrm{p}<0.05)$ from the eight analyzed ones (opportunity to apply one's own ability, career advancement, prestige, individual decision making, and education and personal growth) can be considered significantly dependent at the level of significance of $\alpha=5$. The importance of mentioned motivational factors varied according to the age of women in Slovakia. All age groups of Slovak women perceive motivational factors relating to career aspiration, self-actualization and recognition equally. Therefore, statistically significant correlation was not confirmed $(p>0.05)$.

Table 8. Pearson Chi-Square Test - The Dependence between the Age and Motivational Factor for Women

\begin{tabular}{|c|c|c|c|}
\hline Motivational Factors Relating to Career Aspiration & Chi-Square & $\mathrm{df}$ & $\mathrm{p}$-level \\
\hline Opportunity to Apply One's Own Ability & 36.86 & $\mathrm{df}=12$ & $\mathbf{0 . 0 0 0}$ \\
\hline Career advancement & 47.56 & $\mathrm{df}=12$ & $\mathbf{0 . 0 0 0}$ \\
\hline Working Competences & 19.01 & $\mathrm{df}=12$ & 0.088 \\
\hline Prestige & 35.78 & $\mathrm{df}=12$ & $\mathbf{0 . 0 0 0}$ \\
\hline Individual Decision Making & 32.64 & $\mathrm{df}=12$ & $\mathbf{0 . 0 0 1}$ \\
\hline Self-actualization & 14.73 & $\mathrm{df}=12$ & 0.257 \\
\hline Education and Personal Growth & 78.40 & $\mathrm{df}=12$ & $\mathbf{0 . 0 0 0}$ \\
\hline Recognition & 16.06 & $\mathrm{df}=12$ & 0.188 \\
\hline * Significant motivation factors are in bold. & & \\
\hline
\end{tabular}

Following the calculated residual frequencies, a conclusion associated with the values of importance preferred by individual age groups of women when assessing the importance of five motivational factors relating to career aspiration was drawn. Statistically significant correlation was confirmed (Opportunity to apply one's own ability, Career advancement, Prestige, Individual decision making, and Education and personal growth) (Table 8). Subsequently, the evaluation of importance of motivational factors relating to career aspiration preferred by individual age groups among women was defined (Table 9).

Motivational factor opportunity to apply one's own ability is preferred by women up to 30 years old. Response ranked as 5 (very important) on the scale was the most frequent. It can be supposed that women aged 30 years old are aware of their value on the job market due to their knowledge and completed education. Therefore, the mentioned factor is important for them. Women aged 40 years old consider this factor medium important, maybe because of active family life. Women up to 50 and over 50 years old consider the factor important because they maintain the quality and relevance of professional services throughout their working life.

Career advancement was considered of medium importance (value 3 ) by women aged up to 30 as well as by women up to 40 years old. Subsequently, at the age of 50, it is considered slightly important (value 2). 
Children become adults and it is the last chance to pay attention and keep track of them. The change takes place and value 4 (important) was the most frequent response given from women at the age of 50+. Women are aware of their skills and knowledge, but due to their age their career advancement opportunities are limited.

Prestige is considered very important (value 5) by women aged up to 30 years old as well as by women up to 40 years old. Women up to 50 years old are less interested in prestige, which is why the motivation factor has a value of 4 (important). The motivational factor prestige is considered slightly important (value 2), by women at the age of 50+.

Individual decision making is considered slightly important (value 2) by women aged up to 30 years old. This is due to their inadequate professional and personal skills. The mentioned motivation factor is considered very important (value 5) by women up to 40 years old. The change takes place and value 3 (medium important) is the most frequent at the age of 50+, maybe because of a growing sense of responsibility. At the age of 50+ there is another change and the motivation factor is considered important (value 4).

The value of motivation factor education and personal growth is 5 (very important) according to the evaluation of women aged up to 30 years old and up to 40 years old. Subsequently, the value is 4 (important). The interest in education decreases markedly by women aged 50+ years old and the value of the motivation factor is 2 (slightly important). Women $50+$ years old show a lack of interest at this age.

Table 9. Evaluation of the Importance of Motivation Factors Relating to Career Aspiration Preferred by Individual Age Groups for Women

\begin{tabular}{|c|c|c|c|c|}
\hline \multirow{2}{*}{ Motivational Factors Relating to Career Aspiration } & \multicolumn{5}{|c|}{ Age } \\
\cline { 2 - 5 } & Up to 30 & Up to 40 & Up to 50 & Over 50 \\
\hline Opportunity to Apply One's Own Ability & 5 & 3 & 4 & 4 \\
\hline Career Advancement & 3 & 3 & 2 & 4 \\
\hline Prestige & 5 & 5 & 4 & 3 \\
\hline Individual Decision Making & 2 & 5 & 3 & 4 \\
\hline Education and Personal Growth & 5 & 5 & 4 & 2 \\
\hline
\end{tabular}

Statistically significant correlation can be seen in seven $(\mathrm{p}<0.05)$ of eight studied motivational factors at the level of significance $\alpha=5 \%$ (Table 10) - opportunity to apply one's own ability, career advancement, individual decision making prestige, education and personal growth, self-actualization, recognition. In terms of age, the perception of motivational factor relating to career aspiration working competences is by Slovak men almost statistically significantly dependent $(\mathrm{p}=0.053)$.

Following the calculated residual frequencies, a conclusion associated with values of importance preferred by individual age groups of men when assessing the importance of seven motivation factors relating to career aspiration was drawn. Statistically significant correlation was confirmed (Opportunity to apply one's own ability, Career advancement, Prestige, Individual decision making, Self-actualization, Education and personal growth, and Recognition) (Table 10). Subsequently, the evaluation of the importance of motivation factors relating to career aspiration preferred by individual age groups among men was defined (Table 11). 
Table 10. Results of Pearson's Chi-Square Test - Men

\begin{tabular}{|c|c|c|c|}
\hline Motivational Factors Relating to Career Aspiration & Chi-Square & $\mathrm{df}$ & $\mathrm{p}$-level \\
\hline Opportunity to Apply One's Own Ability & 51.30 & $\mathrm{df}=12$ & $\mathbf{0 . 0 0 0}$ \\
\hline Career Advancement & 39.44 & $\mathrm{df}=12$ & $\mathbf{0 . 0 0 0}$ \\
\hline Working Competences & 20.80 & $\mathrm{df}=12$ & 0.053 \\
\hline Prestige & 56.66 & $\mathrm{df}=12$ & $\mathbf{0 . 0 0 0}$ \\
\hline Individual Decision Making & 55.50 & $\mathrm{df}=12$ & $\mathbf{0 . 0 0 0}$ \\
\hline Self-actualization & 27.54 & $\mathrm{df}=12$ & $\mathbf{0 . 0 0 6}$ \\
\hline Education and Personal Growth & 73.81 & $\mathrm{df}=12$ & $\mathbf{0 . 0 0 0}$ \\
\hline Recognition & 26.17 & $\mathrm{df}=12$ & $\mathbf{0 . 0 1 0}$ \\
\hline * Significant motivation factors are in bold. & & \\
\hline
\end{tabular}

Table 11. Evaluation of the Importance of Motivation Factors Relating to Career Aspiration Preferred by Individual Age Groups for Men

\begin{tabular}{|c|c|c|c|c|}
\hline \multirow{2}{*}{ Motivational Factors Relating to Career Aspiration } & \multicolumn{5}{|c|}{ Age } \\
\cline { 2 - 5 } & Up to 30 & Up to 40 & Up to 50 & Over 50 \\
\hline Opportunity to Apply One's Own Ability & 5 & 4 & 4 & 4 \\
\hline Career Advancement & 5 & 4 & 3 & 4 \\
\hline Prestige & 5 & 4 & 3 & 3 \\
\hline Individual Decision Making & 5 & 4 & 3 & 4 \\
\hline Self-actualization & 5 & 3 & 5 & 4 \\
\hline Education and Personal Growth & 5 & 3 & 3 & 4 \\
\hline Recognition & 5 & 4 & 3 & 3 \\
\hline
\end{tabular}

Men aged up to 30 years old prioritise the motivation factor opportunity to apply one's own ability. It is considered very important (value 5). It is assumed that men start building their career after completion of their studies. They are fully aware of their value on the job market due to their knowledge and completed education. Therefore, being able to apply one's own ability is so important to them. The mentioned factor is considered important by men at higher ages, too. Career advancement is considered very important (value 5) by men aged up to 30 years old and important (value 4) by men up to 40 years old. It is worth noting that there is a decrease at the age of 50 and subsequent increases at the age of 50+. Men over fifty consider the factor important. The evaluation of the motivation factors working competences, prestige, and recognition is almost the same. They are considered very important by men up to 30 years old. The importance of this factor decreases at higher ages of men due to the career that has been already built.

More interesting are the outcomes associated with the motivation factor education and personal growth. It is considered very important (value 5) by men aged up to 30 years old. Subsequently, it is less preferred by men aged up to 40 years old as well as by men aged 50 years old. The value 3 (medium important) was the most frequent response by the male respondents. The evaluation of men aged $50+$ is by the value 4 (important) again. It is possible that men at the age of 50 become aware of trainings ignored by themselves in previous years.

A career is a professional life track for each person. It is associated with personal development, and skill and knowledge acquisition through various education and training 
activities. One's approach to planning and building a satisfying and rewarding career depends upon many factors. Human personality together with priorities and goals play a key role in career development (Čambál and Cagáňová 2010; Bognár 2016).

Following the outcomes of this research, the conclusion that the women's career path in the Slovak Republic is affected by the traditional understanding of the family and the role of women to a large extent can be stated. In the surrounding countries (Poland, Czech Republic, and Germany) the policy is more progressive but it is based on traditional differences in gender roles as well. Factors (Opportunity to apply one's own ability, Career advancement, Prestige, Individual decision making, and Education and personal growth) are preferred by men as well as women. These factors are perceived by both groups in similar ways. Compared to women, men are motivated by recognition and selfactualization; thereby the hypothesis WH1 was confirmed. Following the results of Tables 9 and 11, the fact that motivation factors relating to career aspiration are evaluated using the preferred values of importance by individual age groups of women and men differently can be observed; thereby the hypothesis $\mathrm{WH} 2$ was confirmed. The findings of the authors (Abdullah 2009; Nenkov et al. 2017; Stachová et al. 2017) are similar to the literature. Employees build their career and strengthen the job position within an organization at the same time. Moreover, within a career management program, employees must take part in career counselling in order to discuss their career development through education and professional training. Managers insist on individuality, creativity, and responsibility. It can help employees prepare for a particular job position (Patrick and Kumar 2011).

Despite the fact that Slovak employees working for SMEs operating in the woodprocessing industry prefer motivation factors relating to monetary incentives, relationships, and workplace, motivation factors relating to career aspiration must be taken into account as well. Following the outcomes of this research, careers of Slovak employees can become an important predictor of overall job satisfaction as well as a motivation factor important for the improvment of employee performance. This was already proved by scientific research (London and Raymond 1997; Sankar and Yeong 1997; Sinha et al. 2013; Stopka et al. 2016; Tišlerová 2016; Bekiroglu et al. 2017; Jeong and Choi 2017).

Differences in ages and the impact on motivation factors must be taken into account as well. The study published by the agency HESA (2013) followed by the research conducted by Oxford University (2015) highlighted that age is a key factor affecting career. This factor plays an important role among the large number of factors and career goals. Moreover, it determines the transition of graduates from education to work as well as their monetary reward. Outcomes are based on the research carried out in the year 2013. At that time, 17,000 students of Cambridge University, the Imperial University, the London School of Economics, UCL, Durham University, University of Bristol, and Oxford University participated in the research. This paper demonstrates that even though motivational factors relating to career aspiration are not considered the most important factors by Slovak employees, they are considered very important by men up to 30 and 40 years old. Women up to 30 years old prioritise motivational factors relating to career aspiration and subsequently, after some modification, also women up to 40 years old.

Career growth is very important for employees working in the same area (Mullins 2007). When the organization tends to maintain a high level of productivity, it has to provide education and training possibilities for the employees in order to enhance their knowledge and skills. Organizational structure contributes to the failure of many career development efforts. Hired employees are not appropriate for particular job positions. This means that employees stuck in the wrong job position are not willing to develop (London 
1993). This fact was confirmed in the current study. Education is considered very important by Slovak women aged up to 30 and 40 years old as well as by Slovak men aged up to 30 years old. Men aged 50+ also agree on the importance of education. In some cases, organizations provide creative workspaces to support effective strategies and work solutions. This way, employee performance can be increased and positive relationship towards the organization can be built (Ehrenberger et al. 2015; Kicová and Nadányiová 2015; Barčič et al. 2016; Elkin et al. 2017). Employees feel secure in the workplace as well. Various studies show that employees are seen to have low levels of educational and training qualifications compared to their competitor nations (Goldin and Rouse 2000; Abdullah 2009; HESA 2013). Labor Organisation has reported that more than half of the workforce in manufacturing firms possess only educational qualifications at the primary level or lower. The arguments arise that as well as possessing the required skills for the job and being knowledgeable and trainable, human resources should also be required to possess at least a college or university qualification. However, the generalisation of this standard of education to all levels of employees is unclear and requires further empirical evidence. Nevertheless, it is agreed that an undergraduate degree provides the essential 'intellectual human capital' on which to build future learning and also a knowledge-workforce (Abdullah 2009).

The research results of Farmer (1985), who investigated the relation of sets of influence factors (background, personal, and environmental) with three motivation dimensions (aspiration, mastery motivation, and career commitment), show that background factors had a greater influence on aspiration than on mastery and career commitment. The analyses conducted by Jehanzeb et al. (2012) showed that motivation factors relating to career aspiration such as prestige and working competences can increase the employee satisfaction in the workplace. Despite the fact that this research did not confirm the dominant position of motivation factors relating to career aspiration according to the opinion of Slovak women, however, some women do consider them important. They are key tools for higher performance and personal development.

Motivational factors relating to career aspiration are not affected by politics and economy (Kropivšek et al. 2011; Hitka et al. 2014; Faletar et al. 2015b; Závadský et al. 2015; Faletar et al. 2016). The effect of management, i.e. motivational factors relating to relationship can be seen (Faletar et al. 2015a; Lorincová et al. 2016). An employee motivated by motivational factors relating to career aspiration will tend to move up the corporate ladder (Sánchez-Sellero et al. 2018).

In the circumstances of globalisation and subsequent economical trends it can be stated that the results gathered in the research into SMEs in woodprocessing industry in Slovakia can be used in other regions of the world (Hajdúchová et al. 2016; Hitka et al. 2018). It is necessary to conduct research studies into the issue of large enterprises.

\section{CONCLUSIONS}

1. Slovak small and medium sized wood-processing enterprises must be prepared to cope with differences in motivational factors relating to career aspiration between men and women. This fact must be implemented into corporate culture. Understanding different perceptions and expectations of these groups that profess dual facets of race and gender is perhaps the first step toward diversity management. Research study outcomes support the impact of gender differences on group-level commonalities and differences. 
2. The mentioned outcomes are beneficial to Slovak enterprises in the process of junior and senior management training. Managers in Slovak small and medium-sized woodprocessing enterprises must keep in mind gender as well as age when supporting the career growth of employees. Primarily, younger men (up to 30) must be in the center of attention and subsequently, women (up to 40 years old).

3. Following the research results, managers in Slovak small and medium-sized woodprocessing enterprises have to motivate career-oriented employees especially according to their needs as they are strong predictors of overall job satisfaction. In the long term application of these factors, managers in Slovak small and medium-sized wood-processing enterprises can encourage employees to stay focused on their careers.

\section{ACKNOWLEDGMENTS}

This research was supported by VEGA No. 1/0024/17, Computational model of motivation, APVV-16-0297, Updating of anthropometric database of the Slovak population and, No. VEGA 1/0010/17, Controlling in Slovak enterprises practice in the context of psychological aspects of perceiving its benefits and barriers by internal stakeholders.

\section{REFERENCES CITED}

Abdullah, H. (2009). "Major challenges to the effective management of human resource training and development activities," The Journal of International Social Research $8(2), 11-25$.

Almobaireek, W. N., and Manolova, T. S. (2013). "Entrepreneurial motivations among female university youth in Saudi Arabia," Journal of Business Economics and Management 14(sup1), S56-S75. DOI: 10.3846/16111699.2012.711364

Armstrong, M., and Taylor, S. (2015). Armstrong's Handbook of Human Resource Management Practice, Kogan Page, London, UK.

Arnania-Kepuladze, T. (2010). "Gender stereotypes and gender feature of job motivation: Differences or similarity?" Problems and Perspectives in Management 8(2), 84-93.

Asparouhov, T., and Muthén, B. (2009). "Exploratory structural equation modelling. Structural Equation Modelling," A Multidisciplinary Journal 16(3), 397-438.

Barčič, A. P., Motik, D., Oblak, L., and Vlosky, R. (2016). "Management activity linkages to innovation deconstruction: An exploratory study of the furniture industry in Croatia," BioResources 11(2), 3987-4005. DOI: 10.15376/biores.11.2.3987-4005

Bekiroglu, S., Elmas, G. M., and Yagshiyev, Y. (2017). "Contribution to sustainability and the national economy through recycling waste paper from Istanbul's hotels in Turkey," BioResources 12(4), 6924-6955. DOI: 10.15376/biores.12.4.6924-6955

Bigoness, W. J. (1988). "Sex differences in job attribute preferences," J. Organ. Behav. 9(2), 139-147.

Bognár, T. (2016). "Stages of career path throught useful crises," Acta Oecon. 5(1), 2028.

Brown, S. D., and Lent, R. W. (2012). Career Development and Counseling: Putting Theory and Research to Work, Wiley \& Sons, Hoboken, NJ, USA, pp. 682. 
Buser, T., Niederle, M., and Oosterbeek, H. (2014). "Gender, competitiveness, and career choices," The Quarterly Journal of Economics 129(3), 1409-1447. DOI: 10.1093/qje/qju009

Byrd, T. A., Sankar, C. S., and Loh, L. (1996). "Strategies to improve job satisfaction of U.S. technical personnel," Eng. Manag. J. 8(4), 33-42. DOI: 10.1080/10429247.1996.11414916

Čambál, M., and Cagáňová, D. (2010). Corporate Culture Influence on Effective Initialization and Application of Knowledge Management in Enterprises, Famalicão, PT.

Chenhall, R. H., and Chapman, C. S. (2006). Theorising and Testing Fit in Contingency Research on Management Control Systems, Spiramus, London, UK.

Deal, J. J. (2007). Retiring the Generation Gap: How Employees Young and Old Can Find Common Ground, Jossey-Bass, San Francisco, CA, USA.

Demir, M., Demir, S. S., and Nield, K. (2015). "The relationship between personorganization fit, organizational identification and work outcomes," J. Bus Econ. Manag. 16(2), 369-386. DOI: 10.3846/16111699.2013.785975

Ehrenberger, M., Koudelková, P., and Strielkowski, W. (2015). "Factors influencing innovations in small and medium enterprises in the Czech Republic," Periodica Polytechnica Social and Management Sciences 23(2), 73-83. DOI: 10.3311/PPso.7737

Elkin, S. E., Elkina, O. S., and Metelev, S. Y. (2017). "Design methods of human development management system," International Journal for Quality Research 11(3), 559-572. DOI: 10.18421/IJQR11.03-05

Faletar, J., Jelačić, D., and Dučić, A. (2015a). "Motivation factors in wood processing company," in: $26^{\text {th }}$ International Conference on Wood Science and Technology, International Conference Proceedings, pp. 95-100.

Faletar, J., Previšić, M., Jelačić, D., Dučić, A., and Drimal, M. (2015b). "Motivation of employees in wood processing company before and after restructuring," in: Wood Processing and Furniture Manufacturing Challenges on the World Market and Wood-Based Energy Goes Global - Proceedings of Scientific Papers, pp. 215-220.

Faletar, J., Jelačić, D., Sedliačiková, M., Jazbec, A., and Hajdúchová, I. (2016). "Motivating employees in a wood processing company before and after restructuring," BioResources 11(1), 2504-2515. DOI: 10.15376/biores.11.1.25042515

Farkašová, V. (2015). Communication Skills in Management, Wolters Kluwer SR, Bratislava, SR.

Farmer, H. S. (1985). "Model of career and achievement motivation for women and men,” J. Couns. Psych. 32(3), 363-390. DOI: 10.1037/0022-0167.32.3.363

Farmer, H., Rotella, S., Anderson, C., and Wardrop, J. (1998). "Gender differences in science, math, and technology careers: Prestige level and Holland interest type," $J$. Vocat. Behav. 53(1), 73-96. DOI: 10.1006/jvbe.1997.1608

Fejfarová, M., and Urbancová, H. (2016). "Human resource management in small and medium-sized enterprises in the Czech Republic," Scientific Papers of the University of Pardubice 23(36), 79-90.

Freund, A. M. (2006). "Age-differential motivational consequences of optimization versus compensation focus in younger and older adults," Psychol. Aging 21(2), 240252. DOI: $10.1037 / 0882-7974.21 .2 .240$ 
Goldin, C., and Rouse, C. (2000). "Orchestrating impartiality: The impact of 'blind' auditions on female musicians," Am. Econ. Rev. 90(4), 715-741. DOI: $10.3386 /$ w5 5903

Grybaite, V. (2006). "Analysis of theoretical approaches to gender pay gap," J. Bus. Econ. Manag. 7(2), 85-91. DOI: 10.1080/16111699.2006.9636127

Hajdúchová, I., Sedliačiková, M., Halaj, D., Krištofík, P., Musa, H., and Viszlai, I. (2016). "The Slovakian forest-based sector in the context of globalization," BioResources 11(2), 4808-4820. DOI: 10.15376/biores.11.2.4808-4820

Haveman, H. A., and Beresford, L. S. (2012). "If you're so smart, why aren't you the boss? Explaining the persistent vertical gender gap in management," Ann. Am. Acad. Polit. S.S. 639(1), 114-130. DOI: 10.1177/0002716211418443

HESA. (2013). Higher Education Statistics Agency, HESA, Cheltenham, UK.

Hitka, M. (2009). Model analýzy motivácie zamestnancov výrobných podnikov [Model to Analyse Employee Motivation in Manufacturing Companies], Technická univerzita vo Zvolene, Zvolen, SR.

Hitka, M., and Balážová, Ž. (2015). "The impact of age, education and seniority on motivation of employees," Business: Theory and Practice 16(1), 113-120. DOI: $10.3846 /$ btp.2015.433

Hitka, M., Hajduková, A., and Balážová, Ž. (2014). “Impact of economic crisis on changes in motivation of employees in woodworking industry," Drvna Industrija 65(1), 21-26. DOI: 10.5552/drind.2014.1303

Hitka, M., Lorincová, S., Ližbetinová, L., Pajtinková Bartáková, G., and Merková, M. (2017). "Cluster analysis used as the strategic advantage of human resource management in small and medium-sized enterprises in the wood-processing industry," BioResources 12(4), 7884-7897. DOI: 10.15376/biores.12.4.7884-7897

Hitka, M., Lorincová, S., Pajtinková Bartáková, G., Ližbetinová, L., Štarchoň, P., Li, Ch., Zaborova, E., Markova, T., Schmidtová, J., and Mura, L. (2018). "Strategic tool of human resource management for operation of SMEs in the wood-processing industry," BioResources 13(2), 2759-2774, DOI: 10.15376/biores.13.2.2759-2774

Hofstede, G. (2001). Culture's Consequences: Comparing Values, Behaviours, Institutions, and Organizations Across Nations, Sage Publications, London, UK.

Hofstede, G., Hofstede, G. J., and Minkov, M. (2010). Cultures and Organizations: Software of the Mind, McGraw-Hill, New York, NY, USA.

Ibidunni, S., Osibanjo, O., Adeniji, A., Salau, O. P., and Falola, H. (2016). "Talent retention and organizational performance," Periodica Polytechnica Social and Management Sciences 24(1), 1-13. DOI: 10.3311/PPso.7958

Inceoglu, I., Segers, J., and Bartram, D. (2012). "Age-related differences in work motivation,” J. Occup. Organ. Psych. 85(2), 300-329. DOI: 10.1111/j.20448325.2011.02035.x

ITIM International. (2017). “Geert Hofstede,” (https://geert-hofstede.com/slovakia.html), Accessed on 27 November 2017.

Jehanzeb, K., Rasheed, M. F., Rasheed, A., and Aamir, A. (2012). "Impact of rewards and motivation on job satisfaction in banking sector of Saudi Arabia," International Journal of Business and Social Science 3(21), 272-278.

Jeong, J., and Choi, M. (2017). "The expected job satisfaction affecting entrepreneurial intention as career choice in the cultural and artistic industry," Sustainability 9(10). DOI: $10.3390 / \mathrm{su} 9101689$ 
Kampf, R., Vohodzka, M., Lejsková, P., and Cmíral, T. (2014). "Dependencies of Personal Vehicle Sales on the Financial Support of their Sales," in: $9^{\text {th }}$ International Conference Intelligent Technologies in Logistics and Mechatronics Systems, Lithuania, LI.

Kanfer, R., and Ackerman, P. L. (2004). "Aging, adult development, and work motivation," Acad. Manage. Rev. 29(3), 440-458.

Kicová, E., and Nadányiová, M. (2015). "The possibilities of using BSC concept as a tool or the Strategic management in bus transport companies," in: $19^{\text {th }}$ International Scientific Conference on Transport Means, Lithuania, LI.

Kmec, J., Valenčík, Š., Gombár, M., Kučerka, D., and Vagaská, A. (2016). “Logistics risk identification of new and renovated production machines," Nase More 3, 150155. DOI: $10.17818 / \mathrm{NM} / 2016 / \mathrm{SI} 14$

Kristofik, P. (2002). "Determinants of capital structure and financial decision-making in Slovak enterprises," Ekonomicky Casopis 50(2), 197-216.

Kropivšek, J., Jelačić, D., and Grošelj, P. (2011). "Motivating employees of Slovenian and Croatian wood-industry companies in times of economic downturn," Drvna Industrija 62(2), 97-103. DOI: 10.5552/drind.2011.1040

Ližbetin, J., and Bartuška, L. (2017). "The influence of human factor on congestion formation on urban roads," Procedia Engineer. 187, 206-211. DOI: 10.1016/j.proeng.2017.04.366

London, M. (1993). "Relationships between career motivation, empowerment and support for career development," J. Occup. Organ. Psych. 66(1), 55-69. DOI: 10.1111/j.2044-8325.1993.tb00516.x

London, M., and Raymond, A. N. (1997). "London's career motivation theory: An update on measurement and research," J. Career Assessment 5(1), 61-80.

Lord, R. L., and Farrington, P. A. (2006). "Age-related differences in the motivation of knowledge workers," Eng. Manag. J. 18(3), 20-26. DOI: 10.1080/10429247.2006.11431700

Lorincová, S., Hitka, M., Cambál, M., Szabó, P., and Javorcíková, J. (2016). "Motivational factors influencing senior managers in the forestry and woodprocessing sector in Slovakia," BioResources 11(4), 10339-10348. DOI: 10.15376/biores.11.1. 10339-10348

Machová, R. (2014). "What motivates a human?” Acta Oecon. 3(2).

Mason, R. D., and Lind, D. A. (1990). Statistical Techniques in Business and Economics, Irwin, Boston, MA, USA.

Meece, J. L., Glienke, B. B., and Burg, S. (2006). "Gender and motivation,” J. School Psychol. 44(5), 351-373. DOI: 10.1016/j.jsp.2006.04.004

Milkovich, G. T., and Boudreau, J. W. (1993). Human Resource Management, Grada, Praha, CZ.

Mullins, L. J. (2007). Management and Organizational Behaviour, Prentice Hall, Harlow, UK.

Mura, L., and Machová, R. (2015). "Evaluation of the Innovation Performance of Business Networks," in: $5^{\text {th }}$ Central European Conference in Regional Science, International Conference Proceedings, pp. 634-642.

Myšková, R. (2015). "Assessing the degree of balance between staff dispositions and their job positions using fuzzy logic," Scientific Papers of the University of Pardubice 22(34), 113-124. 
Nenkov, N., Sushchenko, O., and Dyachenko, Y. (2017). "Role of chief information officer within the system of human resource development in service organizations (tourism)," Economic Annals-XXI 165(5-6), 97-103. DOI: 10.21003/ea.V165-20

Očkajová, A., Stebila, J., Rajnicová, H., Gajtanska, M., Igaz, R., Krišt’ák, L., Kubovský, I., Pašková, L., Kvočka, S., and Rybakowski, M. (2013). Pracovné prostredie a ergonómia [Working environment and ergonomics], Belianum, Banská Bystrica, SK.

OECD. (2015). The ABC of gender equality in Education: Aptitude, Behaviour, Confidence, OECD, Paris, FR.

Olsen, W., and Walby, S. (2004). Modelling Gender Pay Gaps, Equal Opportunities Commission, Manchester, UK.

Orhan, M. (2000). A New Model for Analysing Female Entrepreneurship, Brisbane, QLD, AU.

Papp, I. C., Szabó, K., Schwarczová, L., and Hajós, L. (2017). "Expectations and visions of "Z" generation of university students in relation to the labour market," Acta Oecon. 6(1), 23-38.

Patrick, H. A., and Kumar, A. (2011). "Career management, employee development and performance in Indian information technology organizations," Business Management Dynamics 1(5), 24-31.

Peterson, M. (2004). "What men and women value at work: Implications for workplace health," Gender Med. 1(2), 106-124. DOI: 10.1016/S1550-8579(04)80016-0

Podsakoff, P. M., MacKenzie, S. B., Lee, J. Y., and Podsakoff, N. P. (2003). "Common method biases in behavioural research: a critical review of the literature and recommended remedies," J. Appl. Psychol. 88(5), 879. DOI: 10.1037/00219010.88.5.879

Potkány, M. (2008). "Personnel outsourcing processes," E \& M Ekonomie a Management 11(4), 53-62.

Reif, W. E., Newstrom, J. W., and St. Louis, R. D. Jr. (1976). "Sex as a discriminating variable in organizational reward decisions," Academy of Management Journal 19(3), 469-476. DOI: 10.2307/255612

Sánchez-Sellero, M. C., Sánchez-Sellero, P., Cruz-González, M. M., and SánchezSellero, F. J. (2018). "Determinants of job satisfaction in the Spanish wood and paper industries: A comparative study across Spain," Drvna Industrija 69(1), 71-80. DOI: 10.5552/drind.2018.1711

Sankar, C. S., and Yeong, W. Y. (1997). "Factors influencing job satisfaction of technical personnel in the U.S., Singapore, and India," Eng. Manag. J. 9(3), 15-21. DOI: 10.1080/10429247.1997.11414947

Sardak, S., Bilskaya, O., and Simakhova, A. (2017). "Potential of economy socialisation in the context of globalisation," Economic Annals-XXI 164(3-4), 4-8. DOI: 10.21003/ea.V164-01

Scheer, L. (2007). Biometria, Technical University in Zvolen, Zvolen, Slovakia.

Sinha, A., Gupra, R., and Kutnar, A. (2013). "Sustainable development and green buildings," Drvna Industrija 64(1), 45-53. DOI: 10.5552/drind.2013.1205

Srour, I., Malak, M. A. A., Itani, M., Bakshan, A., and Sidani, Y. (2013). "Career planning and progression for engineering management graduates: An exploratory study," Eng. Manag. J. 25(3), 85-100. DOI: 10.1080/10429247.2013.11431985 
Stachová, K., Stacho, Z., and Vicen, V. (2017). "Efficient involvement of human resources in innovations through effective communication," Business: Theory and Practice 18, 33-42. DOI: 10.3846/btp.2017.004

Stopka, O., Chovancová, M., Ližbetin, J., and Klapita, V. (2016). "Proposal for optimization of the inventory level using the appropriate method for its procurement," Nase More 3, 195-199. DOI: 10.17818/NM/2016/SI22

Tišlerová, K. (2016). "Marketing strategy for effective customer relationship management," in: $27^{\text {th }}$ International Business Information Management Association Conference - Innovation Management and Education Excellence Vision 2020: From Regional Development Sustainability to Global Economic Growth, Milan, IT, pp. 875-879.

Tolbize, A. (2008). Generational Differences in the Workplace, University of Minnesota, Minnesota, MN, USA.

University of Oxford. (2015). Study Reveals Careers 'Gender Gap' for University Graduates, University of Oxford, Oxford, UK.

Vetráková, M., Ďurian, J., Seková, M., and Kaščáková, A. (2016). “Employee retention and development in pulp and paper companies," BioResources 11(4), 9231-9243. DOI: 10.15376/biores.11.4.9231-9243

Wilson, T., and Davides, G. (1999). "The changing career strategies of managers," Career Dev. Int. 4(2), 101-107. DOI: 10.1108/13620439910254731

Závadský, J., Hitka, M., and Potkány, M. (2015). "Changes of employee motivation of Slovak enterprises due to global economic crisis," E a M: Ekonomie a Management 18(1), 57-66. DOI: 10.15240/tul/001/2015-1-005

Zemke, R., Raines, C., and Filipczak, B. (2000). Generations at Work: Managing the Clash of Veterans, Boomers, Xers, and Nexters in your Workplace, AMACOM, New York, NY, USA.

Article submitted: April 4, 2018; Peer review completed: May 24, 2018; Revised version received: June 8, 2018; Accepted: June 10, 2018; Published: July 2, 2018.

DOI: 10.15376/biores.13.3.6300-6320 